\begin{tabular}{|l|l|l||}
\hline \multicolumn{2}{|c|}{ PublisherInfo } \\
\hline \hline PublisherName & $:$ & BioMed Central \\
\hline \hline PublisherLocation & $:$ & London \\
\hline \hline PublisherImprintName & $:$ & BioMed Central \\
\hline \hline
\end{tabular}

\title{
A variant histone controls transcription
}

\begin{tabular}{|l|l|l||}
\hline \multicolumn{2}{|c|}{ ArticleInfo } \\
\hline \hline ArticleID & $:$ & 3831 \\
\hline \hline ArticleDOI & $:$ & $10.1186 /$ gb-spotlight-20001115-02 \\
\hline \hline ArticleCitationID & $:$ & spotlight-20001115-02 \\
\hline \hline ArticleSequenceNumber & $:$ & 268 \\
\hline \hline ArticleCategory & $:$ & Research news \\
\hline \hline ArticleFirstPage & $:$ & 1 \\
\hline \hline ArticleLastPage & $:$ & 2 \\
\hline \hline & & RegistrationDate : 2000-11-15 \\
ArticleHistory & $:$ & OnlineDate $: 2000-11-15$ \\
\hline \hline ArticleCopyright & $:$ & BioMed Central Ltd2000 \\
\hline \hline ArticleGrants & $:$ & \\
\hline \hline ArticleContext & $:$ & 130591111 \\
\hline \hline
\end{tabular}




\section{William Wells}

Email: wells@biotext.com

The histone originally dubbed H2A.F (for funny) but now called H2A.Z is variant but conserved: it differs significantly from the major histone $\mathrm{H} 2 \mathrm{~A}$ proteins but shows greater conservation between species than they do. H2A.Z is essential (at least in flies), its expression is tissue-specific, and it is localized to only some regions of fly polytene chromosomes, but its function has remained elusive. In the October 27 Cell Santisteban et al. find that inclusion of H2A.Z in chromatin regulates transcription (Cell 2000, 103:411-422). They isolate the yeast H2A.Z as a multicopy suppressor of a histone H4 mutation. Depletion of histones usually makes gene transcription less dependent on the SNF/SWI chromatin remodeling complex, but deletion of yeast H2A.Z makes cells highly dependent on this complex. SNF/SWI and H2A.Z appear to act together, for example at the PHO5 gene, where H2A.Z binds specifically in the promoter region. Thus H2A.Z may create higher order chromatin domains that are poised for activation.

\section{References}

1. Conservation of intron position indicates separation of major and variant $\mathrm{H} 2 \mathrm{As}$ is an early event in the evolution of eukaryotes.

2. Cell, [http://www.cell.com/]

This PDF file was created after publication. 